
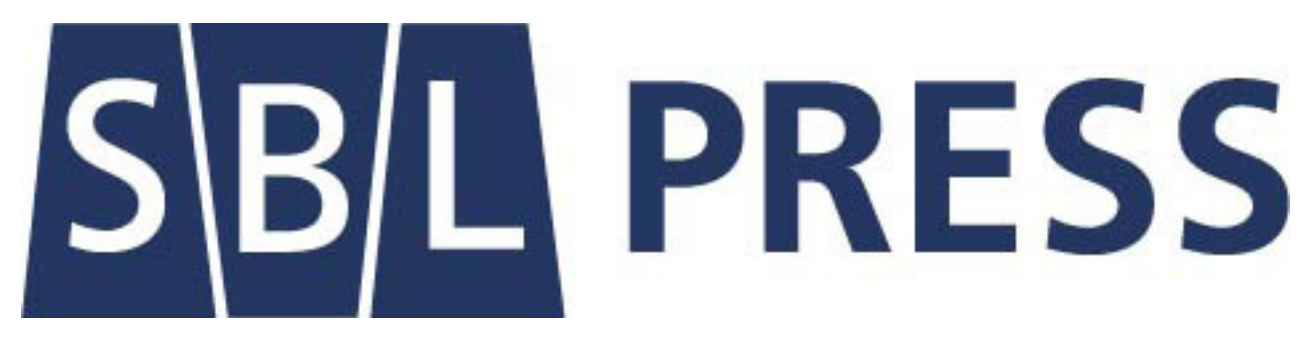

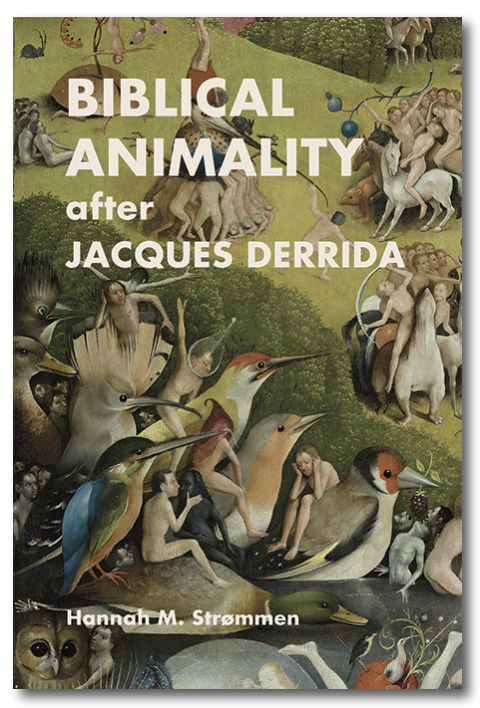

August 2018, 196 pages

Semeia Studies 91

Paperback $\$ 32.95$

ISBN 9781628372120

Hardcover $\$ 47.95$

ISBN 9780884142973

elSBN 9780884142980

\section{Biblical Animality after Jacques Derrida}

\author{
Hannah M. Strømmen \\ A new theoretical and exegetical angle on the Bible and \\ animal studies
}

According to Genesis, humans are made in God's image but animals are not. Hannah M. Strømmen challenges this view by critiquing the boundary between humans and animals in the Bible through the work of philosopher Jacques Derrida. Building on Derrida's The Animal That Therefore I Am, Strømmen brings to light significant moments where the lines between the divine, human, and animal are ambiguous. A rich range of biblical texts is covered, from Noah as the first carnivorous man in Genesis 9 to Revelation's beasts.

\section{Features:}

- A contribution to research on Jacques Derrida and deconstruction

- An examination of Derrida's work on the human/animal boundary

- Critical engagement with the way the Bible is frequently held up as a point of blame for anthropocentrism

Hannah Strømmen is a Senior Lecturer in Biblical Studies at the University of Chichester, UK. Working primarily in the field of reception history and critical theory, she has published on the role of the Bible in literature, the politics of the far right, and animal studies. She recently edited a special issue in Literature and Theology on animals in literature and religion.

\section{PURCHASES, EXAM AND DESK COPIES:}

SBL Press Customer Service

P.O. Box 2243, Williston, VT 05495

Phone: 802-864-6185 / 877-725-3334 (toll-free)

Fax: 802-864-7626

Email: sblpressorders@aidcvt.com

Web: www.sbl-site.org/publications

\section{REQUEST REVIEW COPIES FROM:}

SBL Press

Heather McMurray, Sales Manager

825 Houston Mill Road, Suite 350, Atlanta, GA 30329

Phone: 404-727-3096

Email: heather.mcmurray@sbl-site.org 